\title{
岸沖漂砂を考慮した高知海岸の ヘッドランドの規模・形状の検討
}

\author{
冨永 剛史 1 - 筧 泰昌 1 伊藤 禎和 2 - 大屋 敬之 2 \\ 岩佐 隆広 $3 \cdot$ 宮下 卓也 4 \\ 1 国土交通省 四国地方整備局 高知河川国道事務所（广780-8023 高知県高知市六泉寺町96-7） \\ E-mail: tominaga-t8810@mlit.go.jp, kakehi-y8810@mlit.go.jp \\ 2正会員 株式会社建設技術研究所 大阪本社水システム部（テ541-0045 大阪府大阪市中央区道修町1-6-7） \\ E-mail:s-itou@ctie.co.jp, ooya@ctie.co.jp \\ 3正会員 株式会社建設技術研究所 東京本社水理センター（テ300-2651 茨城県つくば市鬼ヶ窪1047-27） \\ E-mail: iwasa@ctie.co.jp \\ 4学生会員 京都大学大学院 工学研究科（广611-0011 京都府宇治市五ヶ庄）(元 建設技術研究所 職員) \\ E-mail: miyashita.takuya.47n@ st.kyoto-u.ac.jp
}

\begin{abstract}
岸沖漂砂による地形変化が卓越することもある高知海岸長浜〜新居工区におけるへッドランドの規模・形 状を検討するために, 高波浪時の岸沖漂砂特性, ヘッドランド周辺の沖向き流れに着目して, 海浜変形予 測および水理模型実験を実施し, 岸沖漂砂を考慮した長期, 短期の海浜変形モデルを構築した。 同モデル を用いて, 複数の対策案について海岸保全, 施設安定などの視点でヘッドランドの効果を予測評価した結 果, 横突堤追加案が最適となる結果を得た。また, 水理模型実験及び波浪・流況解析により, 海浜の安定 性や施設周辺の流況を踏まえて, ヘッドランドの諸元を設定した.
\end{abstract}

Key Words : Artificial Headland, Cross-shore Sediment Transport, Hydraulic Model Experiment, Kochi Coast

\section{1. はじめに}

高知海岸は，土佐湾の湾奥部にあたる高知県中部に位 置し，西は土佐市荻岬から東は香南市手結岬に至る砂浜 海岸である. 高知海岸では, 供給土砂の減少等による砂 浜海岸の侵食, 海岸堤防の老朽化が進行しており, 抜本 的な対策を早急に講じる必要性から，1968年に南国工区 1996年に長浜〜新居工区が直轄海岸（国土交通省）に指 定された. 本稿は，この内の長浜〜新居工区を対象とし た検討結果を報告するものである.

長浜〜新居工区の位置図を図-1に示寸，当工区では， 突堤延長300 m〜400 mのヘッドランドと養浜による保全 施設整備計画が策定され，暫定計画として $150 \mathrm{~m}$ 突堤の 施設整備が進められてきた. 堤長 $150 \mathrm{~m}$ の突堤の整備完 了箇所では，砂浜が再生され，高潮及び海岸侵食による 被害軽減に効果を発揮している.

一方で，2004年～2005年に発生した高波浪により，こ れまでの移動限界水深（水深9 $\mathrm{m}$ 程度）を越える水深 15 $\mathrm{m}$ 程度までの顕著な岸沖漂砂による海浜変形が確認され, 岸沖漂砂による地形変化量が沿岸漂砂による変化量より 卓越する場合があることが確認された1).

本稿では，岸沖漂砂を考慮した長期および短期スパン
の地形変化を結合した海浜変形モデルを構築した上で, 海浜安定性の確保を目的とした最適なへッドランドの規 模・形状を検討した．高波浪時の岸沖漂砂による海浜変 形に加えて，ヘッドランドに沿った沖向き流れに着目し て海浜変形予測と移動床の水理模型実験を実施し，また， シミュレーションでは表現が困難な施設諸元に応じた局 所的な流況・地形変化や養浜土砂の挙動を把握するため, 移動床の水理模型実験を実施した. これらの結果をもと に, 様々な形状のヘッドランドに対して波浪・流況解析 を実施し，沖向き流れを制御する施設形状を検討した。 本稿における検討フローを図-2に示す.

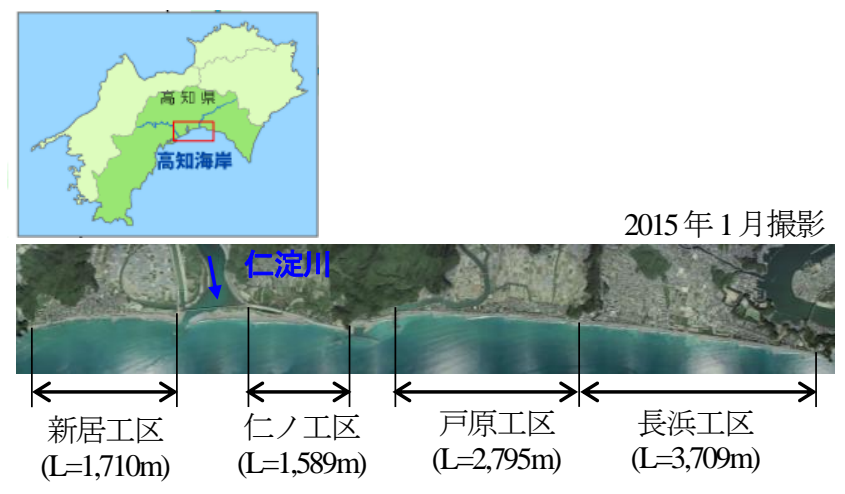

図-1 直轄高知海岸(長浜〜新居工区)の位置図 


\begin{tabular}{|c|c|}
\hline 水理模型実験 & 海浜変形モデルの構築 \\
\hline 施設周辺の流況, 地形変化の把握 & 岸沖・沿岸漂砂統合モデルの構築 \\
\hline 施設周辺の流況 (岸沖流速) & 岸沖 : 施設周辺の岸沖方向流速 \\
\hline 施設周辺の地形変化 & 沿岸: 沿岸漂砂量水深分布 \\
\hline 有力案妥当性確認のための実験 & $\boldsymbol{\Psi}$ \\
\hline & 対策案の検討 \\
\hline 波浪・流況解析 & 長期間（30 年間） の土砂収支 \\
\hline 様々な突堤形状の流況予測 & 高波浪時の土砂流出防止効果 \\
\hline $\begin{array}{l}\text { 突堤形状の䦽 } \\
\mathbf{v}\end{array}$ & $\begin{array}{l}\text { 台風時の哭堤間の汀線囘きの変化 } \\
\text { による堤防倒壊リスク軽減効果 } \\
\end{array}$ \\
\hline & \\
\hline
\end{tabular}

図-2 検討のフロー

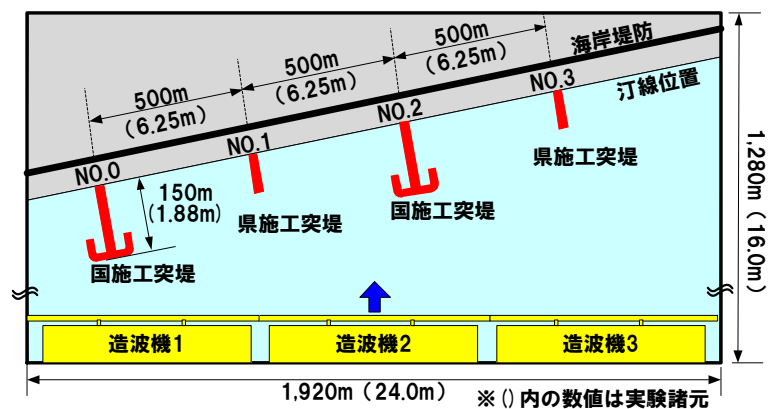

図-3 実験施設のレイアウト

\section{2. 水理模型実験による流況，地形変化の把握}

\section{(1) 水理模型実験の概要}

数值解析では予測が困難な施設諸元に応じた局所的な 流況・地形変化と養浜砂の挙動を把握し，解析に反映さ せるため，縮尺1/80の移動床水理模型実験を実施した．

本検討では，国土技術政策総合研究所の海洋沿岸実験 施設内の幅 $24.0 \mathrm{~m}$ ，延長 $16.0 \mathrm{~m}$ ，高さ $1.0 \mathrm{~m}$ 平面水槽を 使用した。実駼施設のレイアウトを図-3に示寸.

実験は，水槽内に対象とする高知海岸の長浜工区内の 地形を移動床（0.3 mmの単一粒径）により整形し，その 地形上に木製の突堤模型（天端高T.P.2.4 m : 現地と同様 に越波を許容する形状）を設置した状態で実施した。

実験波浪は不規則波とし，現地の観測データをもとに 有義波高・周期，入射角度を表-1のように，突堤諸元を 表-2のように設定した．実験では，突堤近傍の流速を造 波終了直前に電磁流速計，造波前後の突堤近傍の海浜地 形をレーザー式砂面計により計測した。 なお，突堤形状 は，後述の図-9に示す4ケースを実施した.

\section{(2) 突堤周辺の流況及び地形変化特性}

図-4に高波浪時の突堤周辺の流速を示寸．なお，流速 は岸沖漂砂に着目するため岸沖成分を示す．Case1（現 行事業計画) では，突堤先端より岸側の領域において突 堤に沿った沖向きの流れが卓越しており，平均流速（現 地換算值）が $2 \mathrm{~m} / \mathrm{s}$ 程度となる。一方, Case4（横突堤追 加案）では，突堤沿いの沖向き流れが抑制され，平均流 速が $1 \mathrm{~m} / \mathrm{s}$ 程度となり，横突堤による施設沖向きへの流速 が抑制されることが確認できた．図-5に高波浪時，低波
表-1 実験波浪条件の一覧

\begin{tabular}{|c|c|c|}
\hline \multicolumn{2}{|c|}{ 波浪種別 } & 不規則波 \\
\hline \multicolumn{2}{|c|}{ スペクトル } & 修正ブレットシュナイダー・光易 \\
\hline \multirow{3}{*}{$\begin{array}{c}\text { 高波浪 } \\
\text { （造波8時間） }\end{array}$} & 有義波高 & $12.0 \mathrm{~cm}$ \\
\hline & 有義周期 & $1.0 \mathrm{~s}$ \\
\hline & 人射角度 & 汀線直角方向に対して $8^{\circ}$ 西向き \\
\hline \multirow{3}{*}{$\begin{array}{c}\text { 低波浪 } \\
\text { （造波8時間） }\end{array}$} & 有義波高 & $3.1 \mathrm{~cm}$ \\
\hline & 有義周期 & $1.4 \mathrm{~s}$ \\
\hline & 入射角度 & 汀線直角方向に対して $8^{\circ}$ 西向き \\
\hline \multirow{3}{*}{$\begin{array}{c}\text { 年数回 } \\
\text { 生起波 } \\
\text { (造波4時間) }\end{array}$} & 有義波高 & $6.9 \mathrm{~cm}$ \\
\hline & 有義周期 & $1.4 \mathrm{~s}$ \\
\hline & 入射角度 & 汀線直角方向に対して $16^{\circ}$ 西向き \\
\hline \multicolumn{2}{|c|}{ 潮位 } & $40 \mathrm{~cm} \approx 1$ \\
\hline
\end{tabular}

※1: 水槽床版高を現地のT. P. $-32.0 \mathrm{~m} に$ 設定したときの水深

表-2 突堤諸元の一覧

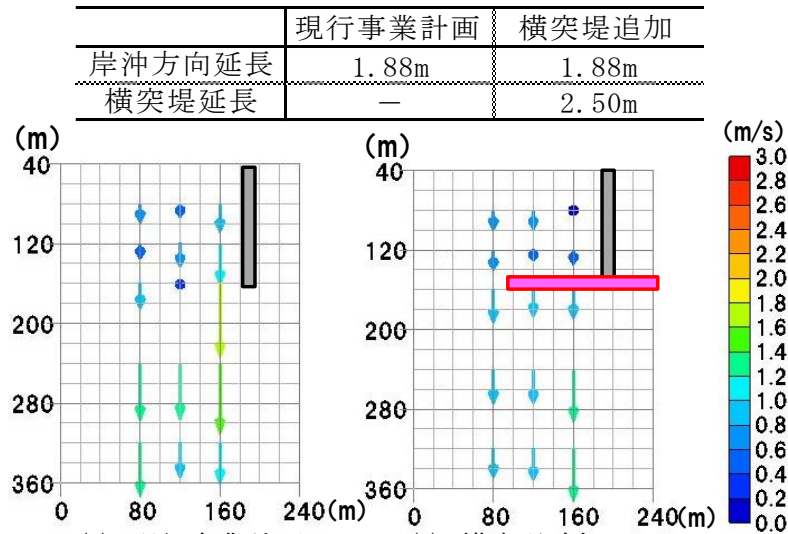

（1）現行事業計画 （2）横突堤追加

※流速ベクトル始点が流速計測地点を示す。

図-4 突堤形状ごとの岸沖方向流速の比較（高波浪）

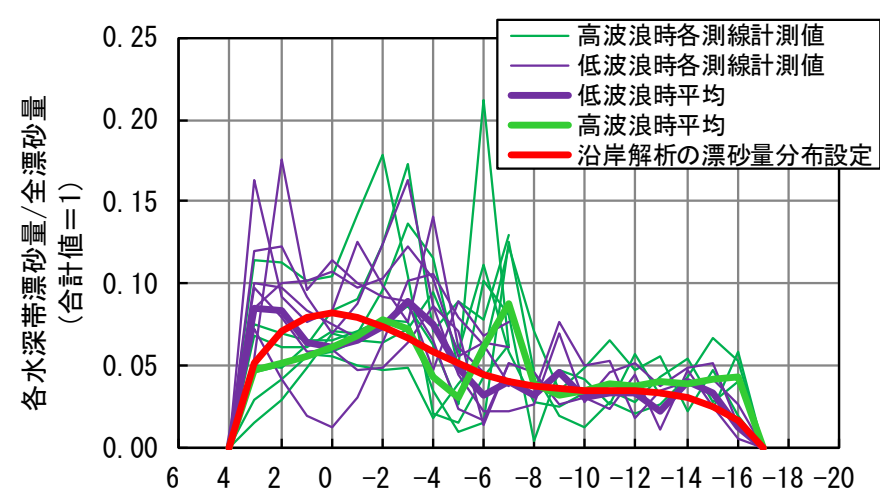

図-5 水深帯別の土砂移動量割合

標高 (T. P. m)

浪時の地形変動量を水深別に整理する．高知海岸の漂砂 特性を確認するため, 突堤形状は現況地形に近いCase1 とし，沖向漂砂が卓越する波浪条件に対して突堤上手側 の測線を対象に整理した。漂砂は水深 $17 \mathrm{~m}$ 付近まで発生 する分布となっており，高知海岸で高波浪時に漂砂が確 認された水深 $15 \mathrm{~m}$ 程度と同程度であり，概水実態を表現 できていると考えられる．本結果をもとに後述の沿岸漂 砂解析における漂砂分布を設定した.

\section{3. 海浜変形モデルの構築}

海岸保全対策の検討に用いる海浜変形モデルは，岸沖 漂砂が卓越する場合もある高知海岸の漂砂特性を表現で 


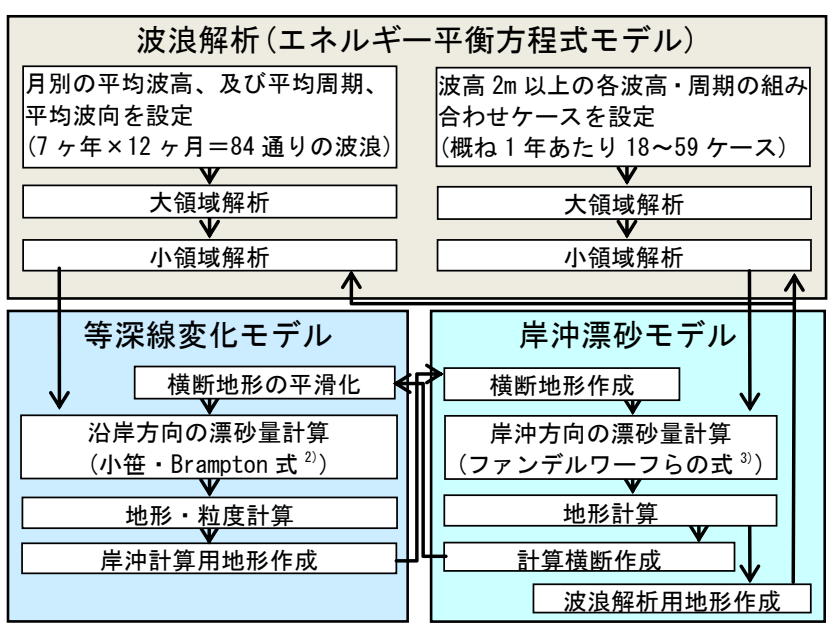

図-6 統合モデルの計算フロー

きること, 各種対策の効果を適切に表現できること，長 期的な解析が実務レベルで実施可能なことが求められる。

これに対して，沿岸漂砂モデルと岸沖漂砂モデルを組 み合わせた岸沖・沿岸漂砂統合モデルにより, 高知海岸 の漂砂特性が概ね再現できることが確認されている4).

本研究では，同モデルを基本に各種対策案の効果を適 切に評価でき，長期解析が可能なモデルを構築すること を目的として，前述の移動床の水理模型実験より得られ た岸沖漂砂特性やヘッドランド周辺の流速特性を考慮し， 同モデルの改良を行っている.

\section{(1) 岸沖・沿岸漂砂統合モデルの概要}

岸沖・沿岸漂砂統合モデルは，波浪解析にエネルギー 平衡方程式，岸沖漂砂にファンデルワーフらのモデル ${ }^{3)}$, 沿岸漂砂に等深線変化モデルを適用した。また，それぞ れの計算結果を相互の地形条件に反映させることで，統 合を図っている．図一6に計算フローを示寸．

波浪解析の外力は，等深線変化モデルでは，近傍の戸 原観測所の毎時データに基づき，月別に波高，周期，波 向(年間12パターン)を設定し，岸沖漂砂モデルでは，対 象年における $2.0 \mathrm{~m}$ 以上の波高に対して波高 $0.5 \mathrm{mピッチ,}$ 周期1秒ピッチで生起時間数を整理し，波高・周期の組 み合わせ(年間18〜 59パターン)を設定した。これにより， 実務での長期解析が可能となった.

\section{(2) 施設周辺の漂砂 · 流況特性の反映方法}

\section{a) 突堤周辺における岸沖流速分布の設定}

施設形状による施設周辺の流況の変化を表現するため には，メッシュサイズを数m以下とする必要があるが, 長期間の解析では計算時間が膨大となり現時点では実務 上で困難となる．

本研究では，解析メッシュサイズを $20 \mathrm{~m}$ とした上で, 前述の水理模型実験から得られた流速変化より，施設形 状別に流速の変化量を整理して，波浪解析で得られる施
表-3 海浜変形解析の計算条件(再現計算)

\begin{tabular}{|c|c|c|}
\hline \multicolumn{2}{|r|}{ 検証項目 } & 内 容 \\
\hline \multicolumn{2}{|c|}{$\begin{array}{c}\text { 解析対象範囲 } \\
\text { (メッシュサイ゙ }\end{array}$} & $\begin{array}{l}\text { 波浪 (大領域) : 岸沖 } 12 \mathrm{~km}, \text { 沿岸 } 18 \mathrm{~km}(\Delta \mathrm{x}=100 \mathrm{~m}) \\
\text { 波浪 (小領域) : 岸沖 } 6 \mathrm{~km}, \text { 沿岸 } 16 \mathrm{~km}(\Delta \mathrm{x}=20 \mathrm{~m}) \\
\text { 地形変化 : 岸沖 } 1.7 \mathrm{~km}, \text { 沿岸 } 12.0 \mathrm{~km}(\Delta \mathrm{x}=20 \mathrm{~m})\end{array}$ \\
\hline \multirow{3}{*}{$\begin{array}{l}\text { 波 } \\
\text { 浪 } \\
\text { 解 } \\
\text { 析 } \\
\end{array}$} & 計算期間 & 7年間（2006年～2013年） \\
\hline & $\begin{array}{c}\begin{array}{c}\text { 入射波 } \\
\text { 条件 }\end{array}\end{array}$ & $\begin{array}{l}\text { 沿岸:実績より月平均波高、周期、波向を設定 } \\
\text { 岸沖:奏績より波高－周期パターンを設定 }\end{array}$ \\
\hline & 地形条件 & $\begin{array}{l}\text { 海浜変形解析の計算地形を } 1 \text { 年毎に受け渡し、 } \\
\text { 小領域において繰り返し計算を実施。 } \\
\end{array}$ \\
\hline \multirow{11}{*}{$\begin{array}{l}\text { 地 } \\
\text { 形 } \\
\text { 変 } \\
\text { 化 } \\
\text { 解 } \\
\text { 析 }\end{array}$} & 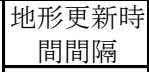 & 1年毎に更新 \\
\hline & 入射波 & $\begin{array}{l}\text { 沿岸:砕波点相当水深位置の波高・波向を設定 } \\
\text { 岸沖:計算測線で岸沖方向波高分布を設定 } \\
\end{array}$ \\
\hline & 流出土砂 & 仁淀川の河川流出土砂 $\left(9.75\right.$ 万 $^{3} /$ 年) を設定 \\
\hline & 沿岸漂砂離 & 後述の移動床水理模型実験の地形変動量より沿 \\
\hline & 岸分布 & 岸漂砂量の水深分布を設定。 \\
\hline & $\begin{array}{l}\text { 漂砂量 } \\
\text { 係数 }\end{array}$ & $\begin{array}{l}\text { 沿岸: 漂砂量係数 } \mathrm{A} ; \mathrm{A}=0.017 、 \mathrm{~K} 2=0.81 \times \mathrm{K} 1 \\
\text { 年沖: } \beta=5.5\end{array}$ \\
\hline & 限界勾配 & 陸上: $\tan \theta \mathrm{g}=1 / 1.7$ 、海中 : $\tan \theta \mathrm{g}=1 / 2$ \\
\hline & $\begin{array}{l}\text { 底質粒度 } \\
\text { 分布 }\end{array}$ & $\begin{array}{l}\text { 沿岸:底質調査より水深別に6区分で設定 } \\
\text { 岸沖:底質調より水深別の代表粒径D } D_{50} \text { を設定 }\end{array}$ \\
\hline & \begin{tabular}{|c|} 
浚渫・投入 \\
土砂量 \\
\end{tabular} & 没定 \\
\hline & 構造物 & 建設年に併せて設定 \\
\hline & 砂移動芒 & 下化分存夻，女1-託 \\
\hline
\end{tabular}

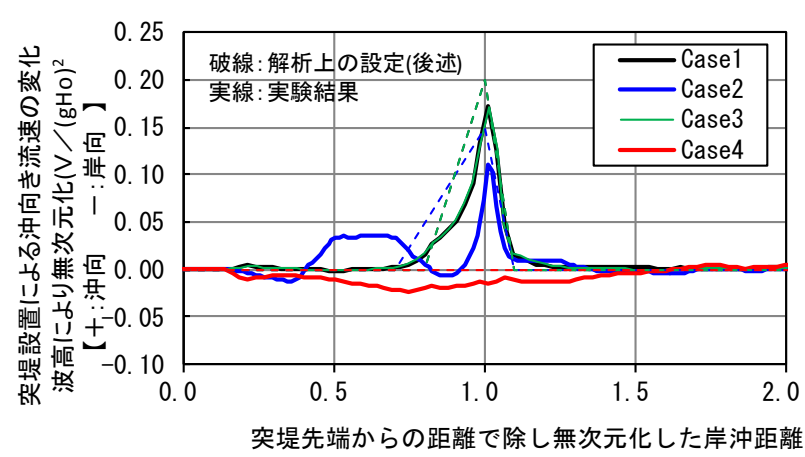

図-7 突堤周辺における流速分布

設周辺メッシュの流速を補正することとした(図-7)。 な お，流速変化は波高で無次元化しており，補正する際に は，波浪条件に応じて補正量を変化させることとした。

b) 沿岸漂砂量水深分布の設定

前述の水理模型実験により得られた高波浪時，低波浪 時の水深帯と漂砂量の関係性（図-5）に基づき等深線変 化モデルにより地形変化計算を実施することとした。 こ れにより，高知海岸の漂砂特性である高波浪時に現地で 確認された水深 $15 \mathrm{~m}$ 付近までの土砂移動を表現した.

\section{(3) 海浜変形の再現計算}

再現計算は，高波浪時の沿岸漂砂による海浜変形を含 む2006年〜2013年の7年間を対象とした．表-3に計算条 件を示す，漂砂量係数は，沿岸漂砂では，感度分析計算 により区間別沿岸方向土砂収支の実績との誤差量が最小 となる定数を設定し，岸沖漂砂では，大規模な断面変化 が発生した2004年の地形変化の再現性より設定した.

図-8上段に再現検証期間における実測，計算の地形変 化分布図，下段の棒グラフに区間毎の土砂変動量，点表 

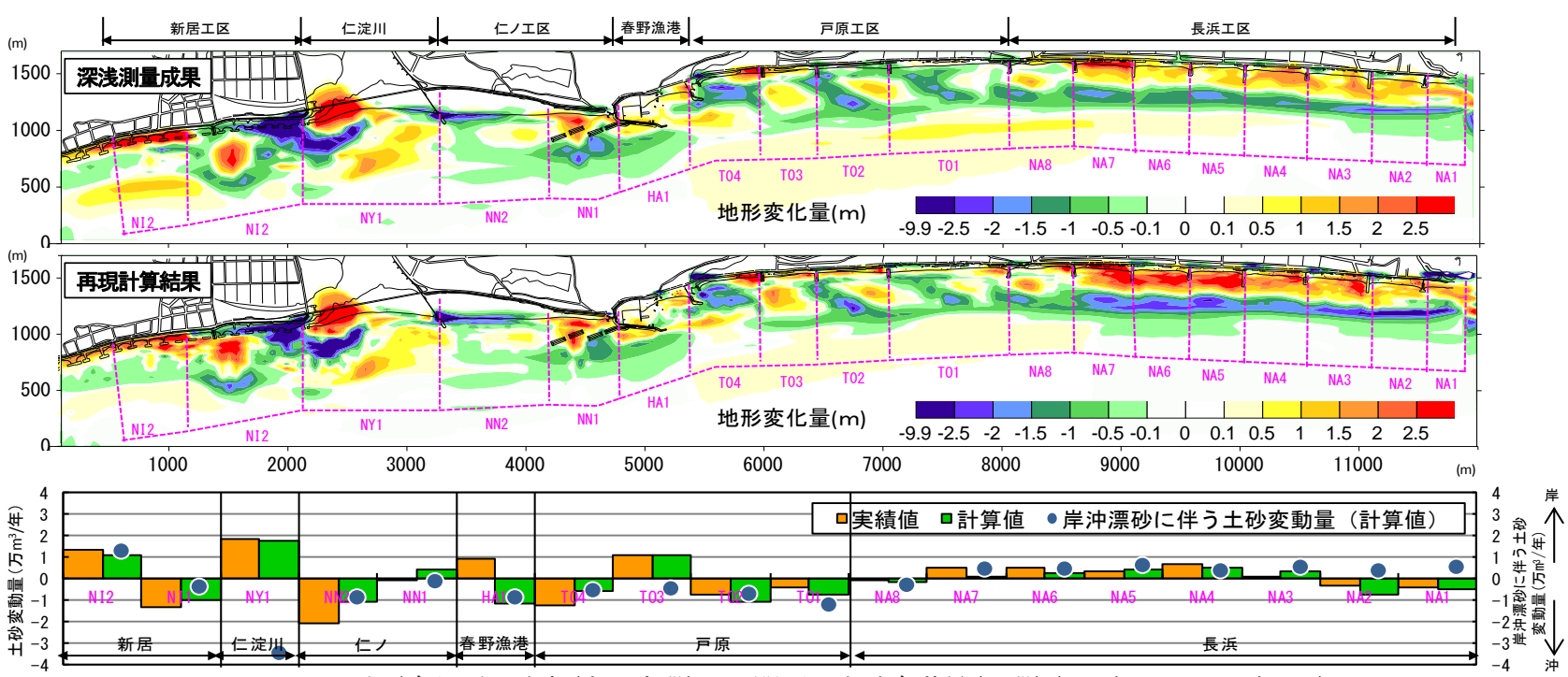

図-8 地形変化平面分布(上・中段)，区間別の土砂変動量(下段) (2006年1月～2013年1月)

記で岸沖漂砂に伴う土砂変動量の計算值を示す.

再現計算結果は，戸原工区で侵食傾向，長浜工区で堆 積傾向等の土砂の侵食・堆積特性が表現できた。区間別 の土砂変動量は実測值と概ね一致した。また，岸沖漂砂 に伴う土砂変動量は戸原工区で沖向，長浜工区で岸向の 傾向であり，実測の傾向が表現できた。実績の汀線や移 動限界水深（約15m）以浅の等深線形状も概ね一致した。

\section{4. 対策案の検討}

\section{(1) 対策案の評価の視点}

構築したモデルを用いて，図-9に示寸対策案に対して, 長期間(30年間)の沿岸部の土砂収支，高波浪時の沖側へ の土砂流出防止効果，台風時の波向きに応じた突堤間の 汀線向きの変化による堤防倒壊リスクの軽減効果に着目 して，予測計算を行った。予測計算条件を表-4に示寸.

\section{(2) 予測計算結果}

図-10にCase1，Case4の30年間の地形変化量の平面分布， 図-11にCase1，Case4の地形変化量の差分(Case4-Case1)を 示す. Case1, Case4ともに施設周辺の汀線付近で堆積傾 向が確認される.また，Case1 とCase4の比較ではCase4が Case1より横突堤より岸側において堆積傾向であり，特 に突堤周辺で顕著となっている.

図-12に各対策案の施設岸側(図-10中ピンク破線内)の 30年間の工区別土砂変動量を示寸．30年後の施設岸側の 土砂堆積は，Case4が最も堆積が大きく，戸原工区で29.1 万 $\mathrm{m}^{3} / 30$ 年，長浜工区で 10.7 万 $\mathrm{m}^{3} 30$ 年となる．横突堤に よる施設岸側への土砂捕捉効果と考えられる.

図-13に高波浪時(2力年)における汀線付近（汀線から 沖合 $150 \mathrm{~m}$ の範囲）の土砂変動量を示寸．高波浪時の戸 原工区の汀線付近から流出する土砂量は，Case1で41.6 万 $\mathrm{m}^{3} /$ 年, Case4で 40.1 万 $\mathrm{m}^{3} /$ 年となり, 横突堤により汀線
Case 1: 現行事業計画 (突堤長 150m)

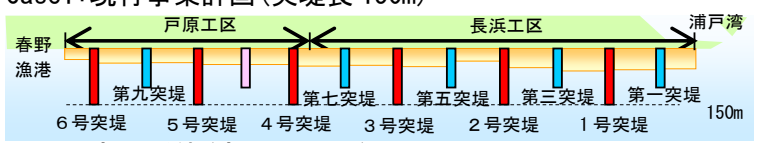
Case2: 突堤延伸 (突堤長 $300 m$ )

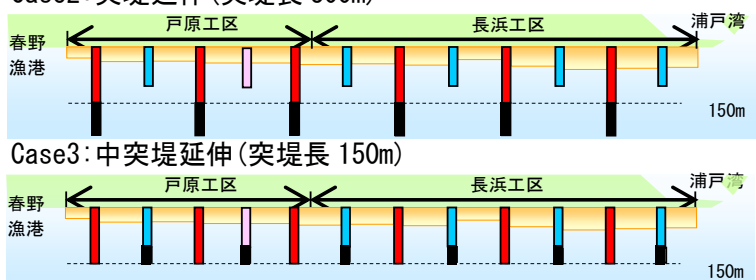

Case4:横突堤追加

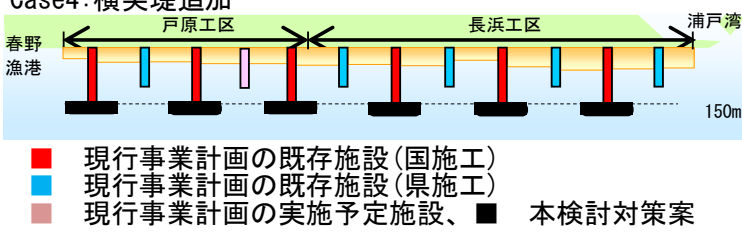

図-9＼cjkstart突堤による対策案の設定

表-4 海浜変形解析の計算条件 (予測計算)

\begin{tabular}{|c|c|c|}
\hline \multicolumn{2}{|c|}{ 項目 } & 設 定 \\
\hline 30 & 計算期間 & 30年間 \\
\hline 年 & 初期地形 & 2015年1月測量地形 \\
\hline $\begin{array}{l}\text { 間 } \\
\text { の }\end{array}$ & 波浪条件 & $\begin{array}{l}\text { 1997年〜2014年の18年間分の実績波浪(波高・ } \\
\text { 波向)を繰り返し設定 }\end{array}$ \\
\hline $\begin{array}{l}\text { 解 } \\
\text { 析 }\end{array}$ & 養浜 & $\begin{array}{l}\text { 仁淀川水系河川整備計画における河道掘削土量 } \\
\left(57 万 \mathrm{~m}^{3}\right) \text { を30年間で利用するものとして設定 }\end{array}$ \\
\hline \multirow{2}{*}{$\begin{array}{l}\text { 高 } \\
\text { 波 }\end{array}$} & 計算期間 & 2年間：高波浪年（2004年〜 2005年)を設定 \\
\hline & 初期地形 & 2015年1月測量地形 \\
\hline \multirow{2}{*}{$\begin{array}{l}\text { 泿 } \\
\text { 時 } \\
\text { 解 } \\
\end{array}$} & 波浪条件 & $\begin{array}{l}\text { 2年間：高波浪年（2004年〜 2005年)の実績波 } \\
\text { 浪(波高・波向)を設定 }\end{array}$ \\
\hline & 養浜 & なし \\
\hline \multirow{4}{*}{$\begin{array}{l}\text { 台 } \\
\text { 風 } \\
\text { 期 } \\
\text { の } \\
\text { 解 } \\
\text { 析 }\end{array}$} & 計算期間 & 1日間 \\
\hline & 初期地形 & 2015年1月測量地形 \\
\hline & 波浪条件 & $\begin{array}{l}\text { 2004年以降の台風期で、有義波高 } 2 \mathrm{~m} \text { 以上とな } \\
\text { る全期間のエネルギ一平均波高、エネルギー平 } \\
\text { 均周期、最も西寄り・東寄りの波向きを設定 } \\
\text { ・波高 : } 4 \mathrm{~m} \text { 、周期 : } 11 \text { 秒 } \\
\text { ・西寄 : 汀線の直角方向に対して } 22^{\circ} \text { 西寄り } \\
\text { •東寄 : 汀線の直角方向に対して } 30^{\circ} \text { 東寄り }\end{array}$ \\
\hline & 養浜 & なし \\
\hline
\end{tabular}



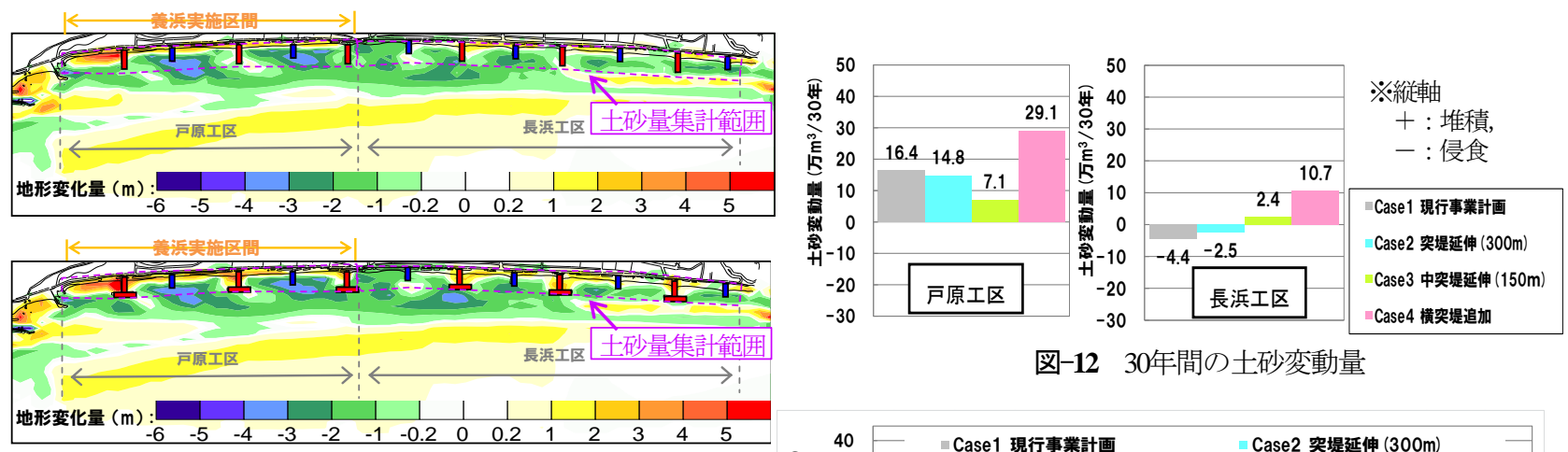

図-1230年間の土砂変動量

図-10 30年後地形変化(上段 : Case1, 下段 : Case4)
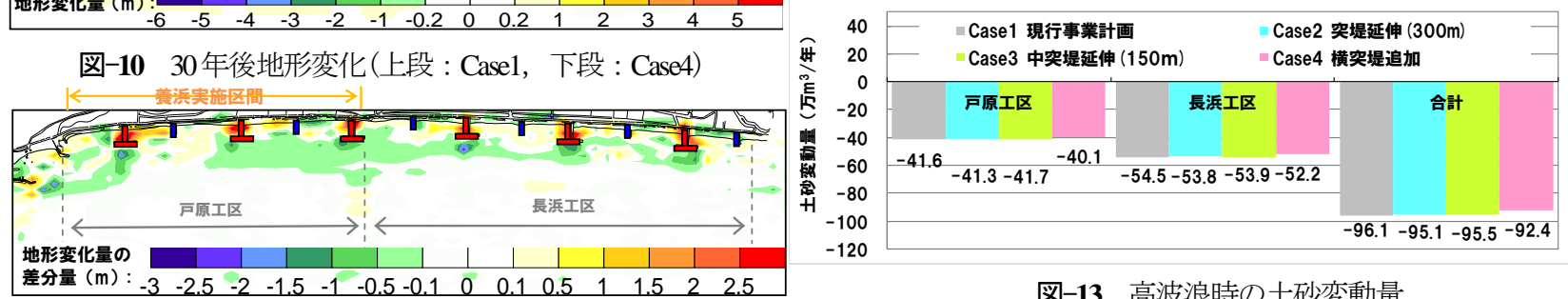

図-13 高波浪時の土砂変動量

図-11 地形変化量の差分 (Case4-Case1)

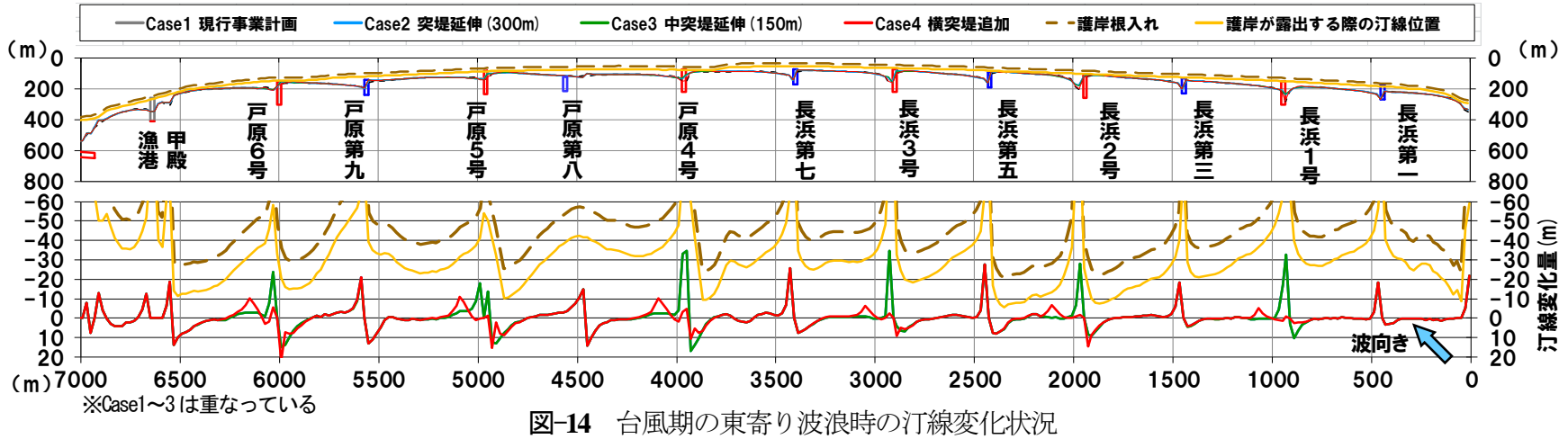

表-5 流況解析の計算条件

付近より沖側への土砂流出量を 1.5 万 $\mathrm{m}^{3} /$ 年軽減できる.

図-14に台風期の東寄り波浪時の汀線変化を示寸. Case1では長浜1 3突堤，戸原4～6号突堤で約 $40 \mathrm{~m}$ の汀線 の後退が確認されるが，Case4では汀線後退は約 $10 \mathrm{~m}$ あり，横突堤の追加により汀線後退が軽減された。

以上より，長期間の海浜安定効果，高波浪時の土砂流 出防止効果が最も大きく，台風期における局所的侵食が 軽減されるCase4(横突堤追加)を有力案として選定した.

\section{5. 波浪・流況解析及び水理模型実験による施設 諸元の設定}

\section{（1） 波浪・流況解析による施設規模・形状の選定}

前章で選定した有力案(Case4(横突堤追加))は，横突堤 の延長は200 m，直線形状としている。ここでは，波 浪・海浜流解析により横突堤の延長・形状を検討した.

検討では，汀線の安定性や施設沖側への土砂流出抑制 を念頭に，各形状の突堤先端部背後の汀線付近の流速， 縦突堤近傍の沖向き流速，横突堤背後の流速に着目し， ケース間で相対的に評価した．表-5に計算条件を示寸．

図-15に横突堤延長・形状別の対策案の流速ベクトル 分布を示寸. 汀線付近流速，横突堤背後の流速，横突堤 先端付近の沖向き流速を比較すると，横突堤延長 $200 \mathrm{~m}$

\begin{tabular}{|c|c|}
\hline 項 目 & 内 容 \\
\hline 基礎方程式 & ブシネスク方程式 \\
\hline 解析範囲 & 岸沖 $1,650 \mathrm{~m} \times$ 沿岸 $3,600 \mathrm{~m}$ \\
\hline (メッシュサイズ) & (メッシュサイズ $5 \mathrm{~m} \times 5 \mathrm{~m})$ \\
\hline 地形条件 & $\begin{array}{l}\text { 沿岸方向に一様なモデル 地形（2004.2 測量 } \\
\text { 平均断面の近坝地形 })\end{array}$ \\
\hline $\begin{array}{l}\text { 入射波の波高、 } \\
\text { 周期、入射角度 }\end{array}$ & $\begin{array}{l}\text { 【Step } 1 \cdot 2 】 \text { 計画波浪 } \mathrm{H}=11.8 \mathrm{~m} 、 \mathrm{~T}=15.5 \text { 秒、 } \\
\text { 汀線の直角方向に対して西向 } 16^{\circ} \\
\text { 【Step } 3 \text { 年数回波浪 } \mathrm{H}=6.2 \mathrm{~m} 、 \mathrm{~T}=12.4 \text { 秒 } \\
\text { 急勾配波浪 } \mathrm{H}=10.0 \mathrm{~m}, \mathrm{~T}=10.0 \text { 秒, } \\
\text { 汀線の直角方向に対して西向き } 16^{\circ}\end{array}$ \\
\hline 構造物の処理 & 不透過（完全反射） \\
\hline 底面摩擦係数 & \begin{tabular}{|l} 
水深 $0.08 \mathrm{~m}$ 未満となるメッシュ：0.3 \\
水深 $0.08 \mathrm{~m}$ 上上なるメッシュ : 0.02 \\
\end{tabular} \\
\hline 汀線部の処理 & 無反射境界 (エネルギー吸収帯を設定) \\
\hline
\end{tabular}

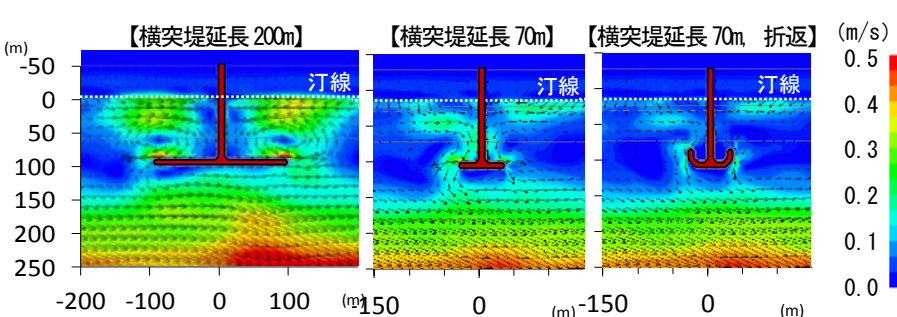

図-15 突堤規模別の流速分布

のケースが横突堤延長70 mのケースより大きくなってお り，70 mのケースの方が背後の汀線後退や，横突堤より 沖側への土砂流出は小さくなると考えられる．また，横 突堤先端に折返しを設けることで，横突堤先端から沖向 きの流速は小さくなり，沖側への土砂流出は抑制される 


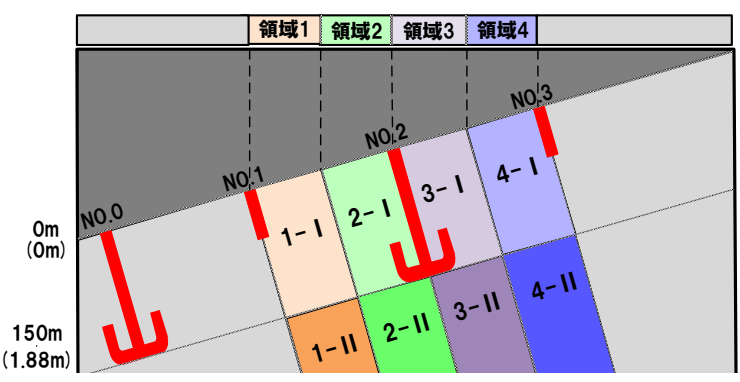

図-16 土砂変動量の評価の領域分割

と考えられる．したがって，施設規模及び形状は，横突 堤延長 $70 \mathrm{~m}$ ，折り返し形状が適切であると考えられる.

\section{（2）水理模型実験による施設形状の妥当性の確認}

横突堤延長70 mの施設について，2.に示した水理模型 実験により折返しによる海浜保全効果を確認した.

沿岸・岸沖方向での空間的な海底変動の傾向を把握す るため，図-16に示すように実験での地形変化範囲内を 沿岸方向には各突堤間の中間を境界として4領域に区分 して，岸沖方向には突堤先端より岸側の領域の土砂変動 量の変化を漂砂捕捉機能として評価した. 表-6に示すよ うに横突堤に折返しを設けた場合には，折返しなしの場 合と比較して突堤先端より岸側の土砂変動量が増加し, 沿岸漂砂を捕捉する効果が期待できることが確認できた.

\section{6. 結論}

（1）模型縮尺 $1 / 80 の$ 移動床の水理模型実験により，突堤周 辺での岸沖方向の流速分析と沿岸漂砂の離岸距離分布 を設定し，高知海岸長浜〜新居工区の海浜変形特性を 表現可能な海浜変形モデルを構築した.

(2)同モデルを用いて，長期（30年間）及び短期（高波浪 期2年間,台風時1日間）を対象に，突堤による対策形 式案別の海浜変形予測解析を実施し, 横突堤追加案が 沿岸部に土砂を留める効果が高いことを確認した。

(3)横突堤の規模・形状別に波浪・流況解析を実施し,
表-6 造波から4時間後の土砂変動量の比較

\begin{tabular}{|c|c|c|c|c|c|}
\hline \multirow[b]{3}{*}{ 施設形状・規模| } & & 単位 & 千 $m^{3}$ & 現地 & ールル) \\
\hline & \multicolumn{5}{|c|}{ 造波から4時間後の土砂変動量 } \\
\hline & 領域 & 領域 & 領域 & 領域 & 領域 \\
\hline $\begin{array}{c}\text { 横突堤延長 } 70 \mathrm{~m} \\
\text { 折返しなし }\end{array}$ & -7.7 & 5.7 & -5.8 & 13.1 & 5.3 \\
\hline $\begin{array}{c}\text { 横突堤延長 } 70 \mathrm{~m} \\
\text { 折返し } 30 \mathrm{~m}\end{array}$ & -1.9 & 14.4 & -5.1 & 16.9 & 24.4 \\
\hline
\end{tabular}

汀線の安定や土砂を留める効果の高い突堤の規模，形 状として横突堤70 m，折返し30 mの形状を設定した. また，移動床水理模型実験により同形状の突堤は，沿 岸漂砂を捕捉する効果が期待できることが確認できた. (4)以上の検討結果を踏まえ, 汀線付近からの土砂流出 を抑制し，かつ越波被害を解消する対策として，現行 事業計画にヘッドランドを追加した海岸保全対策を立 案した.

謝辞 : 本研究のとりまとめにあたり，「高知海岸保全技 術検討委員会」 (委員長 出口一郎 大阪大学名誉教授 において数々のご指導を頂いた. ここに記して深甚なる 感謝の意を表す.

\section{参考文献}

1) 森本精郎，久藤勝明，矢野慎二，熟田正樹，赤川嘉 幸: 直轄高知海岸の土砂動態解析と土砂管理計画, 海 岸工学論文集，第 53 巻, pp.516-520, 2006.

2) 小笹博昭, Brampton, A.H.:護岸のある汀線変化計算, 港湾技術研究所報告, 第 18 巻, 第 4 号, pp.77104,1979.

3) Jebbe J. van der Werf, Jan S. Ribberink. and Tom O'Donoghue:DEVELOPMENT OF A NEW PRACTICAL MODEL FOR SAND TRANSPORT INDUCED BY NON-BREAKING WAVES AND CURRENTS,Coastal Sediments, pp.1-14, 2007.

4) 祭田佳奈江，熟田正樹：岸沖漂砂の卓越する海岸にお ける岸沖・沿岸漂砂統合モデル開発，土木学会論文 集 B3(海洋開発)，Vol.68, No.2, pp.I_612-I_617, 2012.

(2017.3.15 受付)

\section{CONSIDERATION OF SIZE AND SHAPE OF ARTIFICIAL HEADLANDS IN KOCHI COAST CONSIDERING CROSS-SHORE SEDIMENT TRANSPORT}

\section{Takefumi TOMINAGA, Yasumasa KAKEHI, Sadakazu ITOU, Yoshiyuki OYA, Takahiro IWASA and Takuya MIYASHITA}

This research is to design the coastal structures in Kochi Coast where cross-shore sediment transportation is dominant. Cross-shore sediment transportation induced by high waves and current flows near structures was studied by hydraulic model experiments. Then a numerical model that evaluates crossshore and alongshore sand transportation was developed.

Using this model, shore structures' effect as beach protection was evaluated. Artificial Headlands were proposed as the optimum design of the coastal structures. Furthermore, the optimum size and shape of the headlands was proposed by evaluating the beach protection and the flows analysis near structures using the hydraulic and numerical models. 